\title{
Prophet Muhammad (PBUH) in the Holy Quran and Nahj al-Balaghah, and the first volume of the interpretation of Zamakhshari's
}

\author{
Forogh Ahmadi $^{{ }^{*}} \quad$ Jahanshah Ahmadi $^{2} \quad$ Reza Delshad $^{3}$ \\ 1.Science and Research Branch, Islamic Azad University, Ilam, Iran \\ 2.Faculty of Psychology, Karaj Branch, Islamic Azad University, Alborz, Iran \\ 3.Ilam University of Medical Sciences
}

\begin{abstract}
The Prophet of Islam, the Prophet Muhammad (PBUH), is the chosen servant of God, the last of the prophets of the divine religion, the teacher of the verses of wisdom, and the trainer and assistant of human beings. When ignorance and darkness shone in Hejaz, he was summoned from the kingdom of heaven to earth. The most divine angel became earthly and spent all his life with his blessing, filled with many ups and downs, in the direction of guidance of the people and the invitation to the religion of Islam, and with the worship and servitude of the essence of the right to the highest degree of worship and highest peak of humanity.In the Holy Qur'an, the eternal miracle of the great Prophet Muhammad that has always been regarded as the book of human guidance, the Prophet (PBUH) has been very much spoken of. The obedience of the Prophet has been raised along with obedience to God. The persecution and disrespect of the Prophet (PBUH) has been as painful a as torment and damnation of God in this world and the world after, and God's friendship is conditional upon obedience to the Prophet (PBUH). The Divine conduct of the Holy Prophet (peace be upon him) and his mercy and patience are described as the coherence and unity of Muslims and is described by the interpretation of "Surely, you (Prophet Muhammad) are of a great morality" ${ }^{1}$. According to the verses of the Holy Qur'an, which includes more than 500 verses, the existence of the Prophet of Islam (PBUH) is a favor to humanity, a mercy for the universe, an eternal pattern for the human race, and a witness to all the divine prophets. The commander of the believers, Imam Ali, who had always been with the Prophet since childhood, in the valuable book of Nahj al-Balaghah portrays various stages of the Prophet's life during various sermons and speaks of the greatness of the Prophet (PBUH).This study has tried to survey the ethics and behavior of the Holy Prophet (PBUH) in the holy books of the Holy Qur'an and Nahj al-Balaghah, as well as the interpretation of Zamakhshari's Al-Kashshaaf, and there verses, sermons and commentaries in this field have been pointed out. Although no one can claim that this unique personality of the universe has been known to him completely and comprehensibly, so that he can write his knowledge about the Prophet.
\end{abstract}

DOI: $10.7176 / \mathrm{RHSS} / 9-12-12$

Publication date:June $30^{\text {th }} 2019$

\section{Introduction}

When ignorance and darkness had spread in Hejaz, when the daughters of the Arab were buried alive for being girls, when they called the Ka'ba as the main building of idol-worshipping, and when there appeared no sign of honesty, truthfulness and kindness in the Arab community, the most merciful angel of the earth was born, came to justice and brought the right, gave the entire universe color of the God, and the bright sun of his existence spread the light of knowledge and mercy on the earth. He called for monotheism and called to one God, melted the snow of darkness and brought the hope for spring. The heart became the center of the universe and the blank sheet of existence. He was called from the kingdom of heaven to earth, and became the most divine angel of the earth. He sang:

"Read (Prophet Muhammad) in the Name of your Lord who created, (1)

Created the human from a (blood) clot. ( $(r) " 2$

We speaking of Mohammad Mostafa (PBUH), the promoter of the divine religion, the teacher of the verses of wisdom and the instructor and role-model of people. Writing about the greatest of mankind, the chosen ones of the God, is not easy, it is honestly, very difficult. He who claims to be fully and comprehensively informed to write about those chosen. However, in the present text, I try to be able to as much as in my humble knowledge, write about the ethics and behavior, the rituals and traditions of the chosen Prophet and harbinger of the eternal (PBUH). It is hoped that we can always be the guarantor of his religion and enjoy the light of his existence. (Qomi, 1361: 3)

\footnotetext{
${ }^{1} \mathrm{http}: / /$ parsquran.com/data/show.php? sura $=68 \&$ ayat $=4 \&$ user=far\&lang=eng\&tran $=1$

${ }^{2} \mathrm{http}$ :/parsquran.com/data/show.php?sura $=96 \&$ ayat=1\&user=far\&lang=eng\&tran=1
} 


\section{The Prophet's Father}

"His great father is Abdullah bin Abdulmutallab, whose mother is Fatimah, the daughter of Amr ibn Ayaz ibn Imran ibn Mizzom, one of the five Fatimas that are in the lineage of the Prophet. Abutaleb and Zubair bin Abdulmutallab and five of Abdulmutallab's daughters, with the exception of Safiyah, the mother of Zubair, were born from the same lady. Abdullah's konya (epithet) had been mentioned as Abu Ghasham, Abu Muhammad and Abu Ahmad and his title of honor as Zabiyh. The Prophet's father died in Medina when he was 25 years old, his father's uncles' house among the Bani al-Najjar tribe in a house known as Daralenabagah, and was buried in the same house. It is said that Abdullah bequeathed a servant, five camels, a herd of sheep, an ancient sword and some money, that the Prophet inherited them. "(Mansouri, 1387: 21).

\section{The prophet's mother}

Amenah was the daughter of Wahb bin Abdul Manaf ibn Zohreh ibn Kalab, who married Abdollah 10 years after digging the Zamzam and one year after Abdulmutallab ransomed 100 camels to release Abdullah from death: and six years and three months after giving birth to the Prophet (PBUH) died on a trip that had taken his son to Medina to see his mother's relatives, Bani Yadi bin Al Najjar, when returning to Mecca at the age of thirty in Abūā, and was buried there. "(ibid: 22)

\section{The Prophet's birth}

The dark clouds of ignorance had spread throughout the Arabian Peninsula, ugly and evil acts, bloody campaigns, plunder and filicide, had eradicated any moral virtues, and the Arab community was on a downturn of a strange misfortune. The distance between their deaths and their lives was too short. At that time, the star of the blessing morning was born, and the dark Arabian environment, became clear with the beloved messenger's auspicious birth (PBUH), and this paved the way of salvation and happiness of a retarded nation. It did not take long for the radius of this sun to clarify the world, with its light, and the foundation of a human civilization was established to spread throughout the world.

\section{The journeys of the Prophet (PBUH) before his marriage}

When he was 12 years old, Muhammad went to Syria on a business trip with his uncle's companion, this trip took place in the tenth Rabi'Alaul of the thirteenth year of the Elephant event. In this journey, a Christian monk called Bahira, saw Muhammad, and noticed the sign of the promised Prophet as he had read in holy books. In order to gain more certainty, Bahira made Muhammad swear to Al-Lat and Al-Uzza (the name of two idols from the idols of Mecca) to tell the truth of what he was going to ask. Muhammad (PBUH) replied, "I am the enemy of those two idols, I only swear to God!" By the answer of Muhammad (PBUH), Bahira found that he was the last Prophet of God who had been promised. When Abutaleb was informed about the matter, ordered him to protect Muhammad from the enemies, because he would take on a major mission in the future. "(Rasulli Mahallati, 1999: 79).

\section{Quality of revelation}

When Muhammad was at the age of forty at one of the nights of Ramadan (in another narration, a night before the 27 th of Rajab), where he was engaged in the worship of God, and secret supplication to the unique creator, in the cave of Hara, Gabriel, the angel of revelation, appeared on him and read verses from the Qur'an to Muhammad (PBUH). Gabriel called on Muhammad (PBUH) to read these verses: "Read (Prophet Muhammad) in the name of your lord who created (1) Created the man from a (blood) clot (2) Read! Your Lord is the most generous (3) He who taught by the pen (4) Taught the human what he did not know (5)"1 (Holy Quran. 96, 1-5)

\section{The first Muslim}

In the view of history and speeches of historians such as Ibn Ishaq, Ibn Hisham and others, it is certain that the first man to believe in the Prophet (PBUH), was Ali ibn Abi Talib and the first woman, was Khadijah, and the companions of the Prophet (PBUH), like Jaber ibn Abdullah and Zaid Ben Argham and Abbas and others have narrated it."(Rasulli Mahallati, 1378: 133)

\section{Torture of Muslims}

Upon hearing the words of the Prophet (PBUH), many of the people of Makkah believed in him and converted to Islam. Bilal, Yasir and Somayeh, Khobab, Ergham, Talha, Zubayr, Osman and Saad were among the first Muslims. By and large, in the first three years, the number of Muhammad's followers reached 20. But every day that passed crackdown unto them grew, so the Prophet (PBUH) decided to expand Islam in other territories and care for his companions to keep them from of torture pagans. To achieve this, a group of Muslims headed by Jafar Bin Abi Taleb, migrated to Ethiopia. In the sixth year of prophet mission, the Qur'ishi concluded a contract in which

\footnotetext{
${ }^{1} \mathrm{http}: / /$ parsquran.com/data/show.php?sura=96\&ayat=1\&user=far\&lang=eng\&tran=1
} 
marriage or sale was forbidden to Abdulmutallab's family; they hanged this treaty on the wall of the Ka'bah. And with this treaty, levied sanctions and prohibitions on the Prophet and his followers. The Prophet (PBUH), with his companions, took refuge in a valley known as "Abu Talib's branches". Tough years passed on the Prophet and his companions there, until, in the year 10 of the mission, the Prophet (PBUH) said that termites had eaten the lines of the treaty that Quraysh had written up. Quraysh accepted if the words of the Prophet had been correct, they would have lifted the sanctions, and by the claim been proved, they did so." (Rasulli Mahallati, 1378: 139).

\section{Philosophy of the mission}

"Read (Prophet Muhammad) in the name of your lord who created (1) Created the man from a (blood) clot (2) Read! Your Lord is the most generous (3) He who taught by the pen (4), Taught the human what he did not know (5)" (Holy Quran. 96, 1-5)

\section{Philosophy of the mission of Prophets (General Prophecy)}

"Allah has surely been gracious to the believers when he sent among them a Messenger from themselves to recite to them his verses, to purify them, and to teach them the book and the wisdom (prophetic sayings), though before that they were in clear error." $(3,164)^{1}$. In this verse, God blesses mankind with this great blessing, which is the blessing of the mission of prophecy. As elsewhere, God bestows on them bless of guidance of faith, and says:

"They regard it as a favor to you that they have submitted! Say: 'Do not regard your submission as a favor to me, rather, it is Allah who bestows upon you a favor by guiding you to belief, if you are truthful" $(49,17)^{2}$.

\section{Prophecy mission's outcome}

Imam Ali (A. S.), made the following remarks about the results of the prophecies of the Prophets:

"Look at the great blessings of Allah, which fell upon them after the revelation of the Prophet (PBUH) - how they tied their obedience to their religion - and invited them to be united How did the divine blessings spread to them on the wings of their dignity, and they filled them with comfort and prosperity! And all the blessings of the righteousness were taken over. They were drowned among the blessings, and they rejoiced in the merry of life, their social affairs were based on the power of the government of Islam, and settled in the light of dignity, and reached a lasting government. Then they became the rulers of the world, and the Sultans on the earth, and they ruled those who ruled in the past, and administered divine laws for those who were administrators of the law, and in the past no one had the power to break their power, and nobody ever dared fight against them. "(Sayed Rati, 2010, sermon 192: 280).

\section{Characteristics of the prophets}

When Moses and Aaron were sent to Pharaoh for the purpose of communicating the divine mission, they refused them for the first time, after which he promised to meet after so many occasions (for the purpose of negotiating). God bid to them good fortune and kindness with the Pharaoh, and insisted that you should not criticize or aggress against him:

"And speak with him with utmost of calmness and patience, may he be warned or fear (and abandon cruelty). (20, 44)

After these discussions, we find that the presence of the prophets is necessary and needful for human beings, and without these apostles, man cannot tread the path to prosperity. We must now take into account the characteristics of divine prophets that can guide and lead the rise and fall of human life. (Alawi Tharakemey, 1377, 449).

\section{Good manners of the prophet (PBUH)}

One of the features that the Holy Qur'an praises the Prophet (PBUH) for, is his good ethics: "And in fact, you are well-adorned by great goodness in hear and demeanor." $(68,4)$

The Great Prophet of Islam (PBUH) is a prominent man and a knowledgeable teacher of human ethics, as God says about him: "You have had a graceful example in the existence and behavior of the messenger of God, for those who have hoped God and the afterlife and have thought God all the time." $(21,33)$

And Amir al-Momenin, Imam Ali (A. S.) says about the Prophet and teaching of the great human morality and practice of his great existence:

"Of course and indeed, I followed him everywhere, every day, like a real and persistent follower by his mentor. He sowed examples of his great and divine demeanor to convince me follow him." (Seyyed Razi, 2010, sermon 192: 284).

\footnotetext{
${ }^{1} \mathrm{http}: / /$ parsquran.com/data/show.php?sura=3\&ayat=\%DB $\% \mathrm{~B} 1 \% \mathrm{DB} \% \mathrm{~B} 6 \% \mathrm{DB} \% \mathrm{~B} 4 \&$ user=far\&lang=eng\&tran=1

${ }^{2} \mathrm{http} / /$ parsquran.com/data/show.php?sura $=49 \&$ ayat $=\% \mathrm{DB} \% \mathrm{~B} 1 \% \mathrm{DB} \% \mathrm{~B} 7 \&$ user=far\&lang=eng\&tran $=1$
} 


\section{Sympathy and empathy}

In the Kashshaaf, it is quoted as follows: "The last verse that was revealed to the Prophet (PBUH) was verse 280 of Surah al-Baqarah, in which Allah almighty states: "And if (someone in your debt) is in need of a retribution to become a rich man, bestow the chance to him, or outlay it (in his poverty) as charity. It is better for you, if you understand." (ibid 2, 280)

When Gabriel revealed this verse for the Prophet (PBUH), he said to him: put it at the head of the two hundred and eighty verse of Surah al-Baqarah. After that, the messenger of Allah (PBUH) was alive for twenty-one days. And some have also said that his life was eighty-one days after the revelation of this verse." (Zamakhshari, 2010, $1,393)$.

\section{Prophet Muhammad (PBUH)'s watchfulness and night prayers}

The true night prayer is the one whose practical worship is in harmony with his inner worship. Hence, the prophet was, in accordance with this verse of Sura al-Asra, well-known for being awake at nights. Based on the verses of Sura al-Imran, he combined his night prayers with pondering over deep concepts. (Tabatabai, 1379, 126)

In his book, Zamakhshari also mentioned, "It is said that the Prophet (PUBH) described the Day of Resurrection to his companions, and that he warned them from the events of the resurrection. People went to the house of Uthman ibn Maza'un, and decided to stay awake at night, fast, and not to eat meat or fat, and not to sleep with women and not to use perfumes until leave the world. When this news came to the Messenger of Allah, he said: "I have not commanded you to do such things. Your body has a right to you. Fast some days, and eat some days; do night prayers some nights, and sleep some nights. Some days I fast, and I do not on some days. I eat meat and fat, and I show interest in women. Whoever turns from my tradition is not from me. "(Zamakhshari, 2010, 1: 823)

\section{Devoutness and piety of the prophet}

The Prophet (PBUH) did not indulge in the world and was not much dependent on it. The two sides of his body were deeper than everyone else, and his stomach was emptier than ever. God showed the showed him the world, but he did not accept. And whatever he knew that God would despise, he despised too, and that which God considered small and insignificant, he considered small and insignificant." (Seyed Razi, 2010, sermon 160, 212)

\section{Brevity, altruism and Jihad of the prophet}

The Prophet fought for God's sake with those who were the barrier to humanity, and he was the leader of the warriors in his campaigns, and he kept his followers from the blows of the infidels and polytheists with the assistance of the people and relatives.

Imam Ali (A. S.) the brave of the bravest and leader of the believers says: "In the cause of God, he fought against his enemies, not weakened or excused." (Seyyed Razi, 1389, sermon 116, 274).

The hypocrites said: Do not be surprised that you are dreaming and he gives you void promises and tells you that Yathrib will see the palaces of Hira and Madaen, and they will be opened to you, while you are digging a ditch to protect yourself from invading different Arab groups that you do not have the power to oppose? "(Zamakhshari, 1389, p 1, 426). Then this verse was revealed:

"O God, O king of the kingdom, you bestow whoever you desire a kingdom and a reign, and from whoever you will desire you will repossess it. You will honor whoever you desire, and degrade whoever you despise, every good and goodness is in your hands. Only you can do everything." (3:26).

On a Friday, when returning from the Friday prayers in Madinah, in the middle of Shawal, he landed in one of the valleys of Ahad, walked around and carefully assembled his companions, and if he saw someone who was ahead of his line he told "Be sure to stay behind." He set up his camp next to the valley and set up his army behind Ahad Samadan and ordered Abdullah ibn Jabir to be the commander of the riflemen and told them to shoot fire to the enemy from behind themselves so that they could not attack us from the back." (Zamakhshari, 2010, 1: 503)

\section{Miracle}

If you bring a sign, if you are the right one, represent it. [Moses (A. S.)] Suddenly threw his cane, and a dragon came out, and brought out his hand from his clothe; it was white for the spectators." (Holy Quran, 7: 106-108)

"Basically, the miracles of witnessing the claims of the prophecy of the Prophets. There have also been many miracles to the Prophet (PBUH), some of which have been quoted to be a total of four thousand." (Qomi, 1361, 146)

What was of purpose of the ascension of the prophets?

It is understood from verses and traditions that the purpose of the prophet's ascension has been three things: "1. Commemorating the angels; 2 . Seeing the wonders and secrets of creation; 3. Retelling it for the people."

Imam Sadegh (A. S.) says: "God is not limited to time and place, but he wanted to respect and glorify the 
angels and inhabitants of his heavens by inviting the Prophet (PBUH) among them, and also wanted to show his great wonders to his messenger, So that he would tell them to people after return. "(Mohammadi Eshtehardi, 1998, p. 2, 400)

It is noteworthy that the flow of ascension is nothing new, but some of the earlier prophets have - of course limited - experienced this, such as the ascension of the Christ (A. S.), "Rather, Allah raised him up to Him. Allah is Almighty, the Wise." $(4,158)$

\section{The Prophet (PBUH) and his family in Nahj al-Balaghah}

In the 94th Nahj al-Balaghah sermon, Imam Ali (A. S.) clarifies the purity and originality of his dynasty. Imam, in this sermon, after the praising of the greatness and mightiness God, has described the divine prophets and ultimately deals with the description of the prophet (PBUH) and states: "Whenever one of the prophets died, a successor - from the prophets' line - continued the religion of God. Finally, the grace of God led to the presence of the Prophet Muhammad (PBUH) and made him of the best mines of the Prophets and the best of the roots, that is, of the genealogy which the prophets have gone through and chosen by God's protectors.

In another sermon Imam Ali says: "We [the Prophet's family] are the center of the divine mission and the center of angels' pass. We are the mines of science and the sources of wisdom. Our helpers and our loved ones are looking forward to God's mercy and our enemies awaiting the wrath of Allah." (Sermon 109, 146)

\section{Shi'a of Prophet (PBUH) not only Shi'a of Imam Ali (A. S.)}

Now that we are talking about the word "Shiite", and the beginning of the emergence of this name and its origin, it's better to quote the words of Imam Ali ibn Abitaleb in the book "Ghadir's Epic". It is stated that Ali (A. S.) in one of the letters that he wrote and advised it to be read to his Shiite, after "Basmalah" says: "This letter is from the servant of Allah, Ali Amir al-Mu'minin, for his believing Shi'as. This name (Shi'a) is a name that God has praised and brought in the Quran. And you are the Shiite of the Prophet himself. This is not a special name for particular people, and this religion is not new." (Hakimi, 1374: 167)

\section{In the grace of the Prophet (PBUH)}

Ali (A. S.) stated in one of his sermons about the virtue and the prophet of Islam: "God placed the Prophets in the finest of havens, and put them in the best position. And continually transmitted them from the righteousness of the fathers to the wombs of the mothers. Whenever one of them died, the other one raised them up for the establishment of religion. Until the grace of God, the Supreme Lord, was given to Muhammad (PBUH). Therefore, God created the Prophet from the most magnificent mines and roots. And from the same tree that the other prophets had experienced. And he appointed his faithful brothers from his family. Her family is the finest. And his relatives are the nicest. And the tree of his generation is the tallest tree. In the openness of thought, and in the grove of dignity he has grown. His branches are tall and his fruits are out of reach. Therefore, the Prophet is the leader of the righteous, and the bright eyes of the wise men, and the bright and glowing stars of the bright, and the brilliant fire. His method is endurance and his way is guidance. His speech is separator of vice and virtue, and his command is justice. He received a mission when the world had not received a prophet for a long time, and the people were wrong in their deed, and the former nations were in wandering and ignorance. Help God bless you and get clear signs of your work. That clear and smooth way calls you to a secure, eternal place. And you are in a pattern in which you can seek God's pleasure in the light of his opportunity and leisure, as the letters have been opened, and the flavors are flowing and running, and the bodies are sound and free, and praiseworthy works are accepted. (Sayyed Razzi, 2010, Sermon 94, 124)

\section{The prophet's resistance to problems through his duty}

The various points that dear God addressed in the Qur'an in different ways is an example of this point that Mohammad worshiped so much that God forbade him from worshipping and said: "We did not send the Qur'an to trouble yourself." $(20,2)$

\section{The prophet's description}

O Merciful Lord! O expander of the earth! And protector of the heavens from collapse! And attractor of the hearts to self-knowledge, whether sweet or harsh. Give your friend best praises and highest blessings to your servant and messenger. The one that prophecy missions ended with and the doors of guidance were opened to all by him." (Sayyed Razzi, 2010, Sermon 72, 84)

"And one [God] who among the uneducated people has inspired a messenger to read and recite his verses and cultivate them, and teach them [the Book of Quran] wisdom, even though they were before in clear error formerly. $(2,63)$ 


\section{The prophet's standing and high position}

"Muhammad is not the father of any of your men and shall not be; but the Messenger of Allah, and the end of the line, and the last of prophets; and Allah knows everything." (40,33)

"O Prophet! Deliver what has been revealed to you from your Lord! And if you do not, you have not fulfilled his mission! God will keep you from the possible risks of the people, and Allah will not guide the unbelievers." $(67,5)$

God has made his dignity cheap for his servants and he estimated the essence of the Prophet from the best of the canons and raised the highest roots from the tree that the prophets had come from, and the trustworthy people of righteousness rose from it. His family is best of families and his relatives are the best relatives. It is a fertile tree with fruits of wisdom sprouting from it. It has branches of abundance and loads that cannot be reached by them. $\mathrm{He}$ is the leader of the clerics and the vision of those who are walking, under the glittering light that shines and the bright star that shines bright and sparkles is in darkness. His way is justice, and his tradition is guiding, his speech separates the right from falsehood and his decree is adjudicative, his time was chosen by the time when the mission was touched and the people were deviated due to lack of guidance, and the previous nations were ignorant." (Seyyed Razzi, 2010, Sermon 94, 124)

"God is a friend and guardian of those who believe and brings them from the darkness of enlightenment; and those who disbelieve, their guardians is Satan, and Allah takes them from light to darkness, and they are fellowcompanions of the fire who will always remain eternal." $(257,2)$

In another sermon when he said that he was returning from Siffin, Ali (A. S.) expressed the magnificent appearance of the Prophet in a frightening darkness of ignorance and polytheism, and depicts the unjust of the time of ignorance as such: I testify that Muhammad (peace be upon him) is a servant and messenger of Allah, whom God sent with a celebrated, universal and eternal ritual, and with clear signs and a celestial book, the illuminating light of the wisdom and the radiant light of guidance was with him, and his decree made the right from the falsehood. He turned away ignorance and made clear the reasons, and bemoaned people from the misfortunes of the past. He was appointed to prophecy when the people were intrigued and the tufts of religion and the bases of guidance were broken. Religion was dispersed and the work of the people was scattered and it was not possible to escape from the troubles, and the path was dark. The guidance was unclean, and the blindness of all people, disobedience to Allah, and the propagation of the devil and humiliation of faith, the foundations of faith were broken up and its signs unknown and its paths were destroyed, the people of the Devil followed and walked in and drove him into the water. Satan, the cause of blinding the people, spread his flag of ignorance on people and swayed hem from God. He lifted and throe them into a deadly throbbing. Everyone was wandering and throbbing ignorance and enthusiasm, and they were lost in their paths and ignorance and sedition were seen everywhere, in the best places that were Mecca, and people were adjacent to the worst idol-worship neighbors. They were not able to sleep, because of the harshness of plunder and murder, and they did not think of death. They cried in their eyes and hearts, and lived in a land, where the tongue of the wise men was closed and silent, and the morons were respectable." (Sayyed Razzi, 2010, Sermon 2, 26)

\section{The Prophet's farewell to his people}

"Muhammad (peace be upon him and his family) is not but a prophet, and there were other messengers before him that passed away. Will you return to your religion of ignorance, if he died naturally or of martyrdom? Therefore, anyone who apostate will not harm God, and, of course, God will grant a good recompense to those who believe in him." $(3,44)$

The Prophet opened his eyes at the last moments of separation and said: Call my brother to come and sit beside my bed. Everyone understood that the purpose was not anyone but Ali (A. S.). The Amir of the Faithful (A. S.) came present, and sat down beside the bed of the Messenger of Allah. After a while, he felt that the Prophet wanted to get out of bed. Ali (A. S.) raised the Prophet and rested him on his chest. It did not take long for the Prophet (PBUH), before the sign of parting appeared in his glorious shrine, and while his head was embraced by his brother and successor, the Amir of the Faithful, the great holy spirit of the divinity, flew to the world of eternity on Monday, the 28th month of the 11th century, when he was 63 years old." (Raad Manesh, 1377: 315 - 319)

O Messenger of Allah! My dear friend, I would be ready to sacrifice my father and mother for you. Indeed, the field of prophecy, divine commandments and heavenly news - which was not interrupted by the death of other messengers - broke up with you (the last of the Prophets), and you are the only one, by whose departure, I am deeply saddened. It is true that my mourning over you, consoles other calamities. Your departure is so much that everyone in your mourning is sad beyond imagination." (Seyyed Razzi, 2010, sermon 235, 334)

Elsewhere he mentions: "O Messenger of Allah! If you had not persuaded us by the fact that you commanded us to patience and tolerance, and had not warned us of grief and contempt, surely in our souls we would have been so crying that our torrential fountain would dry up. And indeed eternal grief are over a few things. What can we do? Death is an unavoidable truth." (Sermon 235, 336). In the same sermon continues: "Again, my dearest of dears, I would sacrifice my father and mother to you, remember us with God and keep us in your sight. " (ibid: 336) 


\section{References}

The Holy Quran

Osoul-e Kaafi, Koleini, Seghat al-Islam, Translation and Descriptions of Persian: Ayatollah Sheikh Mohammad Bagher Kermani, Oswah Publication, Ninth Edition

Al-Mizan, in the commentary of al-Quran, Tabatabai Mohammad Hussein, translated by: Mousavi Hamedani Seyed Mohammad Bagher, Mohammadi Publishing House, Printed in 1345

Ayaneh al-Shi'a, Amin, Seyyed Mohsen, Research and Destruction: Al-Amin Hasan, Beirut: Dar al-Tayyipur, Bita. Alaalam, Zarkilly Khairuddin, Beirut: Dar al-Alam al-Malayeen, Fifth, 1980.

Al-Ansab, Samaani, Abdul Karim, Investigation and Suspension: Al-Barudi, Abdullah Omar, Beirut: Dar alJannan al-Mustafa and Al-Nashir, first edition, 1408

Al-Kamal al-Tharah, Ibn Athir, Rsearch, Beirut, 1385.

Al-Kashshaaf, Zamakhshari, Mahmoud Banafar, Beirut: Dar Keqb al-Arabi, Beata.

Alkani and al-Alqab, Qomi, Sheikh Abbas, Tehran: Al-Sadr School, Beata.

Baharalanvar, Majlisi Mohammad Bagher, Al-Wafa Institute, 1403, 1983, Beirut Lebanon Nemooneh Interpretration, Makaram Shirazi, Naser, et. al, Darolkabat al-Eslamiyah,

Tehran, October 21-28, 2003. Sh

Nahjolbaghah Research, "Nahjolalbagh Parsi in Shrine", Quarterly Journal of Nahj Balabagh Research, No. 1, Autumn 2001.

Translation and Explanation of Nahj-ol-Balaghah, Feyz-ul-Islam Ali Naqi, The Center for the Publishing of Feyzul-Islam, March

Zamakhshari and Kisaf, Zaman Mahdi, Akram, Farzaneh, Seyyed Babak, Sahifeh Mobin, Shah 38, Autumn 85. Sokhnan Ali (AS) from Nahj al-Balaghah, Translator:

Fazel Javad, Scientific Press Institute, 20th edition, 1398 e. Ah

In the vicinity of Nahj al-Balagha, Seyyed Habbaeddin Shahrastani, translated by Seyyed Abbas Mirzadeh Ahari, Publisher: Nahj-ol-Balaghah Foundation, September 1979, pp. 69-72

Description of Nahj al-Balaghah, Ibn Abi al-Hadid, 3, p. 59; Mosad Nahj al-Balaghah, vol 1, p. 187; Description of Nahj al-Balaghah, ibn al-Maysam, vol. 4, p. 147.

Framework of the Quran, Quran Shi Ayatollah ... Seyyed Ali Akbar, Darolkbut al-Islamiyyah, 13 th edition, 1381 $\mathrm{AH}$

Eighth Century, Description of Nahj-ol-Balagh, Artist of Azizullah Attardi, Tehran,

Najjul Balagh Foundation, 1996.

Nahj al-Balaghah, Reza Ostadi, Nahj al-Balaghah Foundation, Oct. 1359

Nahj al-Balaghah, translated by Seyyed Ja'far Shahidi, Tehran, Scientific and Cultural Organization, 1998.

Nahj al-Balagha, correction of Sabhi Saleh, Tehran, Oswah publication, 1415 AH. 